\title{
Domestication versus Foreignization in the Translations of Shakespearean Sonnet Shall I Compare Thee to a Summer's Day? into Arabic
}

\author{
Ahmed M. M. Yousof (*)
}

\section{Abstract}

This study investigates the renderings of English and Arabic selected poems in the light of Venuti's domestication and foreignization approaches. Lawrence Venuti, an American theorist and translator of Italian origins, has come up with the concepts of domestication and foreignization in the context of describing both the theory and practice of translation. The concepts of domestication and foreignization first appeared in Venuti's widely known The Translator's Invisibility: A History of Translation, published in 1995. The data were taken from two authentic sources, which are Mazid's (2018) A Poison Tree and Enani's (2003) The Art of Translation, in addition to a number of professional erudite scholars. The study raises three questions: How do Venuti's two approaches be used and applied to poetry translation and why? What is the most frequently used translation strategy (domestication and foreignization) in translating the selected poems? Which theory of Venuti's two approaches and Lefevere's seven strategies can fit the translation of poetry to maintain its nature? The method adopted in the present study is analytical. The study arrived at the conclusion that the choice of domestication and foreignization is not fixed; they can, however, co-exist. In other words, the two methods should supplement and complement each other in terms of time and spatial factors in poetic translation. The present study endeavors to analyze the decision-making process that the selected translators follow as well as how their orientation affects the way they handle culture-specific references, figurative language, imagery, structure, prosody and so on in the translation.

Keywords: Literary Translation, Poetry Rendering, Domestication, Foreignization, Venuti.

(*) This paper is part of an M.A. thesis entitled :" Domestication and Foreignization in the Translation of Selected Poetry between Arabic and English ", Supervised by Prof. Khalid Mahmoud Tawfeek Faculty of Arts, Cairo University \& Dr. Samir Ahmed Abdel Naeem Faculty of Arts, Sohag University. 


\section{Introduction}

\section{Rendering Poetry}

Rendering poetry has been regarded by many translation scholars and theorists like Eugene Nida and Peter Newmark as the most difficult type of translation, because translation loss is maximal in this case. In his About Translation, Newmark indicates that the reason for this loss refers to "the more the text uses the resources of language and therefore the more important its form, the greater the losses of meaning; the greatest loss is in poetry, since it uses all forms of language". (Newmark, p. 64)

One major translation difficulty confronting translators when attempting to render poetry, is how to translate figures of speech, especially culture-specific images, which represent a dilemma to translators. That is because what is beautiful and fine in one language may sound ugly and odd in another. In other words, what is impressive and effective in one culture may be prosaic and insipid in the target culture. Another major problem resides in the phonic aspect of poetry, that is, part of the pleasure of reading poetry comes from the musicality created by rhyme scheme, rhythm, alliteration, assonance, consonance and so on. That is to say, such details constitute an integral part of the cultural and environmental flavor of the poem.

Translation of poetry is one of the most difficult and challenging tasks for every translator. Returning to Robert Frost's definition, according to which "Poetry is what gets lost in translation" p. 14, we can say that this statement could be considered a controversial among the scholars of translation, but what can be taken for granted is that there is hardly one-toone equivalent when comparing two languages. Even if the translators have a profound knowledge of the source language, they will not be able to create a replica of the original text.

The proposed study focuses on the analysis of processes in the products of literary translation, the poetic one in 
particular. The processes are called domestication and foreignization. Domestication and foreignization are two basic translation strategies, which provide both linguistic and cultural guidance. They are termed by American translation theorist Lawrence Venuti in his widespread book The Translator's Invisibility: A History of Translation, published in 1995. According to him, the former refers to ethnocentric reduction of the foreign text to target-language cultural values bringing the author back home, while the latter is an ethnodeviant pressure on those (cultural) values to register the linguistic and cultural difference of the foreign text, sending the reader abroad.

Generally speaking, domestication designates the type of translation in which a transparent, fluent style is adopted to minimize the strangeness of the foreign text for target language readers, while foreignization means a target text is produced which deliberately breaks target conventions by retaining something of the foreignness of the original (Shuttle worth and Cowie, 1997:59).

\section{Research Questions:}

The study attempts to answer the following questions:

1. How do Venuti's two approaches be used and applied to poetry translation and why?

2. What is the most frequently used translation strategy (domestication and foreignization) in translating the selected poems?

3. Which of Venuti's two approaches and Lefevere's seven strategies can fit the translation of poetry to maintain its nature? 


\section{Review of the Literature The History of Domestication and Foreignization in Translation Studies}

Tardzenyuy (2016) argues that from the antiquity through the middle age and the renaissance right up to the twentieth and twenty-first centuries, translation scholars and theorists have generally prescribed either the literal or free, word for word or sense or sense, source-text-oriented or targettext-oriented, adequate or appropriate, foreignized or domesticated translation strategies or methods, depending on the period, perception or text type. The choice has often been either one or the other and hardly ever a combination of the two. In spite of this clear-cut theoretical divide in translation strategies, the translation, notably of literary texts has often shown that both foreignization and domestication or literal and free translation strategies are used alternatingly and complementarily. The study attempts to show that in prose, poetry and drama translation both foreignization and domestication are used alternatingly and complementarily. Examples are drawn from corpora of prose, poetry and drama translation to show that both the foreignization and domestication translation strategies are used in all three types of translation. The study of Tardzenyuy draws the following conclusions:

1. In prose translation domestication is used more than foreignization.

2. Drama translation, like prose translation, appears to use domestication more than foreignization, but to a lesser degree.

3. Contrary to prose and drama translation, poetry translation employs much more of foreignization than domestication.

Kun (2010) argues that in the numerous ancient Chinese literary works, Hong Lou Meng is considered a jewel. One of the greatest classical Chinese novels written in the mideighteenth century during the reign of Emperor Chien-lung of the Qing Dynasty has widely been popular throughout the last 
two hundred years and more. The stroke of genius describes a vivid historical picture within a whole big family "Jia" in the last times of feudalism in China. It is always considered an "encyclopedia" of Chinese traditional culture and art, covering a wide range of social and family composing, such as architecture, drama, preservation of people's health, cooking and diet, medicine and health, social convention, poetry, art, religion and so on. Up to now, Hong Lou Meng has more than 60 translated versions in 23 different languages, among which 12 are complete, which are the best resources for translation study of Chinese language and culture.

Among all the translated versions, two are popular: one is A Dream of Red Mansions translated by Yang Xianyi and Gladys Yang, and the other is The Story of the Stone translated by David Hawkes and John Minford. And mainly in their two great translation works, they adopted respectively different translation strategies of domestication and foreignization. For a long time there has been the long-lasting disputing of exploitation of domestication and foreignization in translation of literary works. This study is a comparative study of translating strategies of domestication and foreignization from the perspective of translating Chinese couplets in Hong Lou Meng in the two versions of Yang Xianyi and Hawkes, mainly on three basic levels, namely semantic beauty, sound echoing and syntactic balance.

With scientific analysis and comparison in two translated versions and sufficient quotations from the two translation works, we want to stress that the aim of this thesis is not to clearly define the superiority or inferiority of neither domestication nor forergnization in practical use of translation, but with a comparative study into picked examples to confess through a proper mixture of both the untranslatability of Chinese couplet is only the superficial phenomenon while translatability is the true essence of things, and the aesthetic effect of both domestication and foreignization strategies in 
translation can be achieved. The public doubt about interactive relationship between foreignization domestication lies out to be meaningless as long as through the facts that their mutual coexistence in the two translated versions of Chinese couplets, with taking into consideration that the two translations strategies even overlap each other in a certain degree.

The dynamic achievement made by both the translators and target readers through respectively rewriting the language and "rereading" the language should be taken into translators' consideration before they go to translate. Thus, in a dynamic process of the translator's "reproducing", the translation really means reproducing the meaning of source language with the most approximate and most natural equivalents of target language both semantically and stylistically. Translation means communication, the main purpose of which is to exchange cultures. The impossibility of exact recreation does not mean the impossibility of approximation and it is precisely on approximation that good translation of poetic work must be built. In short, a well-defined translation works better.

\section{Significance of the Study:}

This study argues that translation is one of the most significant human activities by which we can recognize the poetic art in one country or nation. In such a case, translatability of poetry is something crucial for cultural exchange, notwithstanding, translators may face some problems in finding the proper equivalence and some parts may remain untranslated, but the art of the poetry translator is to reduce these probable untranslatable concepts.

Poetry in translation opens up new linguistic and esthetic realms of language added to the TL and TRs, accordingly. Poetry translator has to be well-versed and has an artistic taste to produce a poetic product that wins the reader's appeal.

Furthermore, there is no room here to argue about whether or not poetry is translatable as the historic importance 
of poetry translation none can deny. Domestication and foreignization are the ideal paradigm to be applied to poetry rendering, because they are connected with literary translation with Lefevere's taxonomy. The present study is supposed to enlighten poetry translators of utilizing such approaches when rendering in a more effective manner.

The study argues that maintaining such status quo of negligence would lead to forsaking the activity of poetic translation and then disappearing that vital industry and finally the genuine Arabic poetry may become restricted to Arabs but remains locked drawers for English audience, and likewise the genuine English poetry will be limited to either the Britons or the Americans accordingly.

The present study is supposed to sound the alarm of the consequences of indifference toward this sacred duty, since the job of the translator in the first place is a mediator between the English and the Arabic cultures in this case.

The results of the present research may help poetry translators to have background knowledge about different practical approaches and strategies employed in poetry translation. Since the selected poems in question are in different forms of verse, translators are expected to follow a specific model or pattern in translating these forms.

Besides, the findings of the current study may assist translation studies scholars, investigators, researchers, students and others who are interested in poetry translation to have some new notions about the methods of poetry translation. 


\section{Theoretical Framework}

Venuti, an American theorist and translator of Italian origins, has come up with the concepts of domestication and foreignisation in the context of describing the stats quo in both the theory and practice of translation in his widespread book "The Translator's Invisibility" (1995). Venuti proposes two concepts: Domestication and Foreignization approaches to investigate such cultural gaps and linguistic discrepancies between languages.

On the one hand, the concept "Domestication" according to Venuti indicates target-culture-oriented translation in which unusual expressions and terms to the target culture are turned into some familiar and natural ones to make the translated text fluent, intelligible and easy for the target readers.

On the other hand, the term "Foreignization" according to Venuti refers to reproducing a product where the translator is visible or translator's resistance tends toward the author. This attitude resists dominant target language cultural values in order to preserve the linguistic and cultural differences of the foreign text. So as to get the reader realize that he is reading a translation of the work from a foreign culture and an alien language.

In The Translator's Invisibility, Venuti believes that the more fluent the translation, the more invisible the translator and the more visible the meaning of the foreign text, the more intricate the target text. Venuti derived these two terms 'Domestication' and 'Foreignization'- from his readings of Schleiermacher's (1813) well-known lectures on the translator's choice wavering between moving the reader towards the author or the author towards the reader.

Schleiermacher (1813) argued that:

There are only two perspectives. Either the translator leaves the author in peace, as close as possible, and moves the reader toward him or he leaves the reader in peace, as much as possible, and moves the author 


$\begin{array}{lllll}\text { towards him." } & \text { (ibid). } & \text { The former } & \text { refers } & \text { to } \\ \text { "foreignization", } & \text { while } & \text { the latter refers } & \text { to } \\ \text { "domestication. } & & & & \end{array}$

Schleiermacher allows the translator to choose between a domesticating method, an ethno-centric contraction of the foreign text to target language cultural identity and values, bringing the author back home and a foreignizing method, an ethno-deviant constraint on those values to reproduce the linguistic and cultural distinctions of foreign text, sending the reader abroad. (ibid)

(His choice is foreignizing translation).

Some scholars have made a comparison between the two concepts of Venuti as follows: "Domestication versus Foreignization"

Foreignization: Being loyal to the form of SL.

Domestication: Being faithful to the culture of the TL.

Foreignization: Ethno-deviant/Heterogeneity.

Domestication: Ethno-centric/Homogeneity.

Foreignization: Lowly communicative.

Domestication: Highly communicative.

Foreignization: Exact/ Ambiguous/ Unintelligible.

Domestication: Natural/ Clear/ Intelligible.

Foreignization: Source word order.

Domestication: Target word order.

Foreignization: Linguistic/Less fluent.

Domestication: Functional /More fluent.

Foreignization: Culturally non-dominant.

Domestication: Culturally dominant.

Foreignization: Intertextual.

Domestication: Intratextual.

Translation does not only involve giving the equivalent meaning in the Target Language (TL), rather it involves considering the values of the TL and the Source Language (SL) whether they are linguistic values or cultural ones. Some translators prefer changing the SL values and making them 
readable for the TL audience. This is termed Domestication. Others, on the other hand, prefer keeping the values of the SL and exposing audience to them. This is termed Foreignization.

Domestication and foreignization are strategies in translation, regarding the degree to which translators make a text conform to the target culture. Domestication is the strategy of making text closely conform to the culture of the language being translated to, which may involve the loss of information from the source text. Foreignization is the strategy of retaining information from the source text, and involves deliberately breaking the conventions of the target language to preserve its meaning. These strategies have been debated for hundreds of years, but the first person to formulate them in their modern sense was Lawrence Venuti, who introduced them to the field of translation studies in 1995 with his book The Translator's Invisibility: A History of Translation. Venuti's innovation to the field was his view that the dichotomy between domestication and foreignization was an ideological one; he views foreignization as the ethical choice for translators to make.

In his The Scandals of Translation: Towards an Ethics of Difference, Venuti (1998, p. 14) states that "Domestication and foreignization deal with the question of how much a translation assimilates a foreign text to the translating language and culture, and how much it rather signals the differences of that text".

He also states that:

Every translator should look at the translation process through the prism of culture which refracts the source language cultural norms and it is the translator's task to convey them, preserving their meaning and their foreignness, to the target-language text. Every step in the translation process - from the selection of foreign texts to the implementation of translation strategies to the editing, reviewing, and reading of translations-is 
mediated by the diverse cultural values that circulate in the target language. P. 72

Venuti also estimates that the theory and practice of English-language translation has been dominated by submission, by fluent domestication. He strictly criticized the translators who in order to minimize the foreignness of the target text reduce the foreign cultural norms to target-language cultural values. According to Venuti, the domesticating strategy "violently" erases the cultural values and thus creates a text which as if had been written in the target language and which follows the cultural norms of the target reader. He strongly advocates the foreignization strategy, considering it to be "an ethnodeviant pressure on [target-language cultural] values to register the linguistic and cultural difference of the foreign text, sending the reader abroad" (Venuti, p. 74). Thus, an adequate translation would be the one that would highlight the foreignness of the source text and instead of allowing the dominant target culture to assimilate the differences of the source culture, it should rather signal these differences.

In Venuti's perspective, "the foreign elements should be highlighted by the translator to register the linguistic and cultural difference of the foreign text" (Venuti 1995:62). Therefore, Venuti prefers foreignization in handling CSEs.

Whereas Nida, who is regarded as the representative of those who favor domestication, sees domestication as the strategy that seeks to achieve complete naturalness of the expression by means of "dynamic equivalence". Therefore, "the message has to be tailored to the receptor's linguistic needs and cultural expectations." (Munday, 2001, p. 42).

Another overriding problem in translation studies is the contrast between source language oriented and target-language oriented translation. This distinction is hermeneutically significant because it is the only criterion indicating what the consequences of a literary translated work are: in what ways 
can the translation influence the worldview of the TL audience, to what extent the TT language tried to resist the translation, and how can we define the final translation as a new textual phenomenon. Different scholars have attempted to come up with more tangible concepts to describe the dichotomy. Newmark (2009, pp. 28-30) reviews, compares and contrasts the major concepts developed by different scholars including his (Newmark's) semantic and communicative translation, Nida's formal correspondence and functional equivalence, House's overt and covert translation, and Nord's documentary and instrumental translation.

The focus had been on the linguistic level. Since the cultural turn appeared in 1970s, the dispute has been viewed from a brand new perspective - social, cultural and historical. The conflict between domestication and foreignization as opposite translation strategies can be regarded as the cultural and political rather than linguistic extension of the time-worn controversy over free translation and literal translation. (Dongfeng, 2002:24)

Two classes have been shown up after the two concepts in question have gained ground in the world of translation studies; some scholars support and some others oppose. After Venuti has come up with the two approaches and given their definitions, a huge conflict has been made among scholars. They are divided into two camps, but both of them has his/her own justifications.

"Domestication can be defined as a strategy to minimize the strangeness of the foreign text for TL readers" (Venuti 1995: 20). In other words, it refers to the translator's tendency to undertake a successful translation where the translator is invisible or transparent. In such a case, the priority is given to the TRs. Moreover, s/he tries to produce a text that matches the target reader's environment in order to win the reader's approval. Supporters of this trend believe that a 'domesticated 
text' will be more acceptable, enjoyed and understood by the readers whose cultural context might be totally different from that to which the original text belongs. However, those who oppose this trend believe that domestication deprives the original text from its uniqueness and flavor and no 'cultural addition' is introduced to the readers.

On the other hand, foreignization can be defined as a strategy where faithfulness is to the original maintaining the alien culture-specific nature of the ST (Venuti 1995: 50). This implies that the translator's job is to preserve the distinctive identity of the SL. Moreover, this tendency takes the target readers into new cultural and linguistic realms of the original text different from theirs. Supporters of this trend believe that the linguistic and cultural identity of the original text should be produced rather than concealed in order to convey the cultural values, which the original carries. However, those who oppose this trend believe that a 'foreignized text' will be weird, unpalatable and not satisfactory to the readers that may make the verse be translated as a prose, which is not required.

In the field of translation, there has long been a point at issue over the proper translation strategies chosen for the conveyance of cultural elements. The two major ones are foreignization and domestication, which have been the crux of contention since their emergence in translation studies (Hu Cui'e, 2000:7).

Venuti prefers foreignization more than domestication, because the former seems to be more faithful to the source text, stressing that language and culture of the ST must be transferred as much as possible. Moreover, the foreign flavor have to be emerged.

(Venuti 2008: 15-16) Foreignization a 'highly desirable strategic cultural intervention' which seek to 'send the reader abroad' by making the receiving cultural aware of the linguistic and cultural difference inherent in the foreign text. This is to be achieved by a non-fluent, 
estranging or heterogeneous translation style designed to make visible the presence of the translator and to highlight the foreign identity of the ST. This is a way, Venuti says, to counter the unequal and 'violently' domesticating cultural values of the English-language world. (Munday, 2001, P. 173).

On the one hand, Venuti is the representative advocate of foreignization, he openly pronounced that the aim of foreignization is to develop a kind of translation theory and practice to resist the trend of the dominance of the target language, so as to give prominence to the difference between the original and the version in terms of language and culture.

On the other hand, Nida is the representative advocate of domestication. He puts forward the notion of the most natural equivalent. Based on the perspective of society and culture, he puts the target reader into the first place. He thinks that the rendition in the version should be completely natural, that the behavioral mode in the source language should be assimilated into the target readers' cultural sphere.

Such a translational notion does not emphasize the concept that the target readers should accept the behavioral mode in the source language for the understanding of the source message. Importantly, domestication and foreignization are not considered binary opposites but parts of a continuum, and they relate to ethical choices made by the translator in order to expand the receiving culture's range: The terms 'domestication' and 'foreignization' indicate fundamentally ethical attitude towards a foreign text and culture, ethical effects produced by the choice of a text for translation and by the strategy devised to translate it, whereas the terms like 'fluency' and 'resistancy' indicate fundamentally discursive features of translation strategies in relation to the reader's cognitive processing (Venuti, 2008, P. 19). 
Although Venuti advocates foreignizing translation, he is also aware of some of its contradictions:

It is a subjective and relative term that still involves a degree of domestication since it translates a ST for a receiving culture. Indeed, foreignizing depends on the dominant values of the receiving culture because it becomes visible precisely when it departs from those values. However, Venuti stoutly defends foreignizing translations (2008, p. 28). Also, Venuti (ibid., p. 19) emphasizes the culturally variable and historically contingent' nature of the domestication and foreignization (Munday, 2001, P. 174).

After these two concepts have gained ground in the realm of translation, scholars have created some sort of compromise between them, they called it 'neutralization', which represents an impartial area. Neutralization can be defined as the attempt to tackle the culture-specific terms that stand half between the SL and the TL. This study suggests that the role of the translator who handles poetry rendering is to bridge, and not to widen, the cultural and morpho-syntactic gaps between the ST and the TR.

Some scholars handle almost the same point of Venuti's, like Juliane House in her (1977) Translation Quality Assessment and Clifford Landers in his Literary Translation: A Practical Guide (2001).

House discusses the concept of overt and covert translation and says:

Overt translation, the original sociocultural frame is left as intact as possible, given the need of expression in another language. An overt translation is thus quite overtly a translation, as it were a second original. By contrast, in covert translation, the translator can and should attempt to create an equivalent sociocultural event. The task of the translator is then, in a sense, to hide the text's real origin. The translator him/herself 
remains invisible, hiding behind his or her 're-creation' of the original. p. 6

Landers discusses the issue of fluency and transparency and resistance and states that:

Literary translation is that a translation should reproduce in the TL reader the same emotional and psychological reaction produced in the original SL reader. Thus, if the SL reader felt horror or curiosity or amusement, so should the TL reader. This approach is not without hazards, for the question arises as to whether a translator is obligated to reproduce boredom, incoherence, unintentional grammatical lapses, factual errors, etc. p. 14

Moreover, Landers suggests two perspectives that are 'Targeteers' and 'Sourcerers'. Targeteers are TL-oriented, while sourcerers are SL-oriented. As Eco has said:

A source-oriented translation must do everything possible to make the B-language reader understand what the author has thought or said in language A... If Homer sees to repeat 'rosyfingered dawn' too frequently, the translator must not try to vary the epithet just because today's manuals of style insist [otherwise]. The reader has to understand that in those days dawn had rosy fingers whenever it was mentioned, just as these days Washington always has DC. Eco continues, translation is rightfully target-oriented

\section{Methodology}

The method adopted in this thesis is analytical and critical. The study holds an analysis and a critique of the translations of the given selected poems, in order to judge the quality of the product and to examine to what extent the 
translators manage to handle the difficulties and problematic issues.

In order to achieve the purpose of the study, the researcher opts for adopting an anthology of English and Arabic selected poems rendered by Muhammad Enani, professor of Literature and Translation at Cairo University, Bahaa-eddin Muhammad Mazid, Professor of Linguistics and Translation at Sohag University and a number of erudite scholars. The researcher collects most of the data from two authentic sources, which are Enani's (2003) The Art of Translation and Mazid's (2018) A Poison Tree. The data contain different levels of language between English and Arabic.

\section{Analysis and Discussion}

William Shakespeare, 1564 - 1616

Sonnet 18 XVIII (1609)

Shall I compare thee to a summer's day?

Thou art more lovely and more temperate:

Rough winds do shake the darling buds of May,

And summer's lease hath all too short a date;

Sometime too hot the eye of heaven shines,

And often is his gold complexion dimm'd;

And every fair from fair sometime declines,

By chance or nature's changing course untrimm'd;

But thy eternal summer shall not fade,

Nor lose possession of that fair thou ow'st;

Nor shall death brag thou wander'st in his shade,

When in eternal lines to time thou grow'st:

So long as men can breathe or eyes can see,

So long lives this, and this gives life to thee.

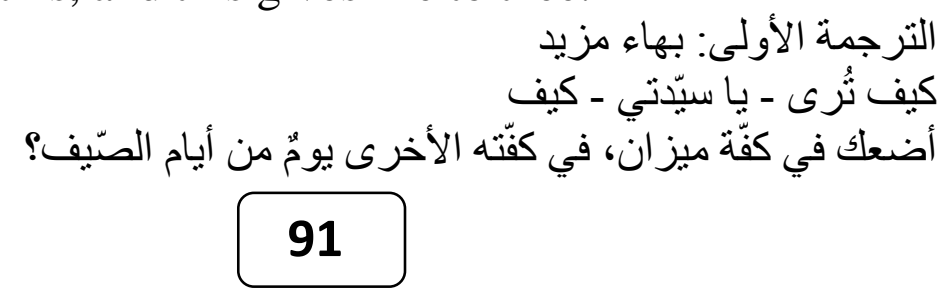




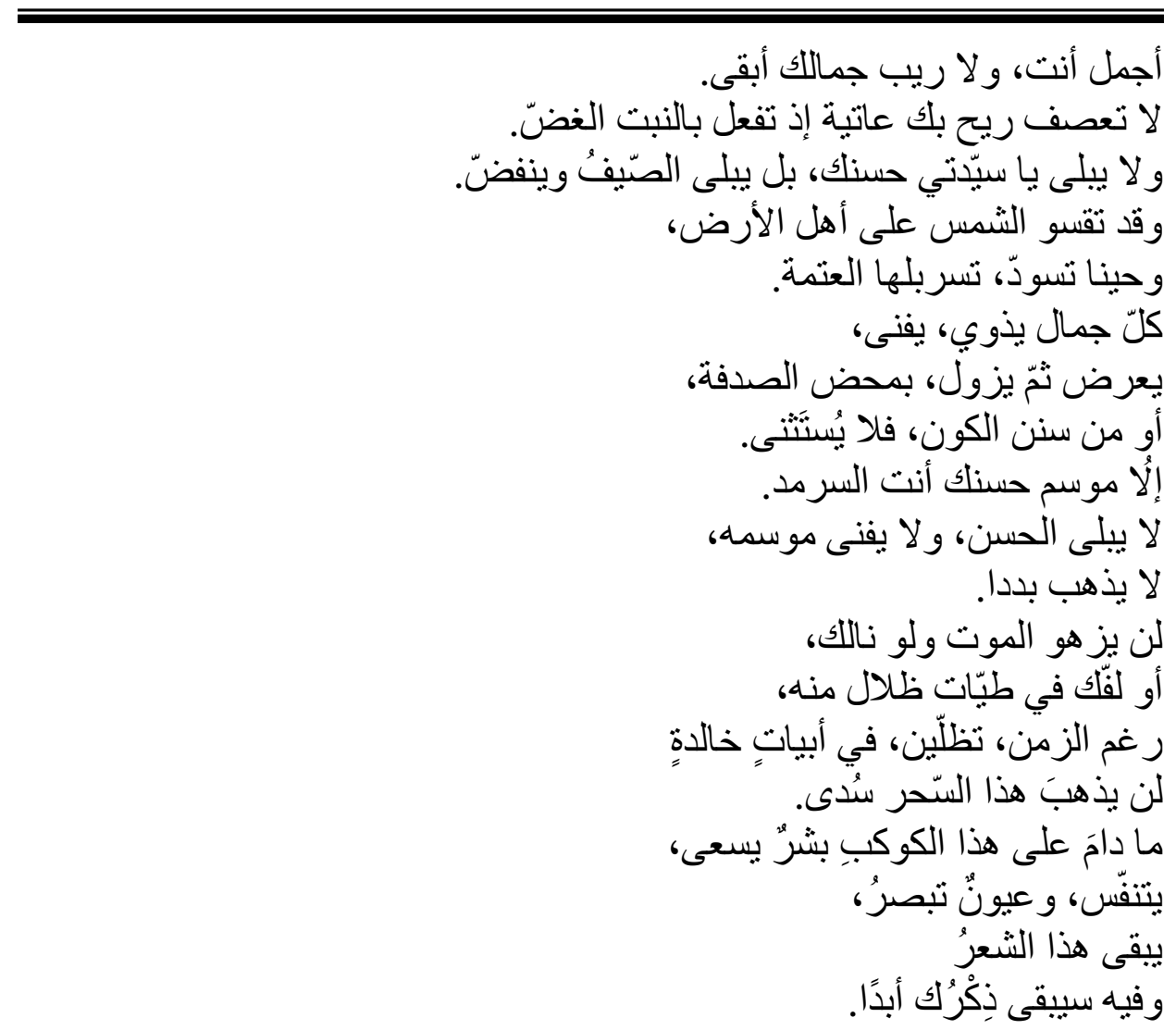

\section{Analysis:}

Mazid did as Venuti said. He believes that the more fluent the translation, the more invisible the translator and the more visible the meaning of the foreign text, the more intricate the target text. Therefore, Mazid follows the foreignizion. He froreignizes the sonnet through his lexical choice that is very near to the original version to deliver not only the language but also the culture. Mazid strikes some sort of a compromise between Lefevere's blank verse in finding the proper equivalents in the target language with a proper semantic result tracing the stylistic qualities of the TLC and Lefevere's interpreting translation when retaining the content of the original depending entirely on the aesthetic canons of the TLC.

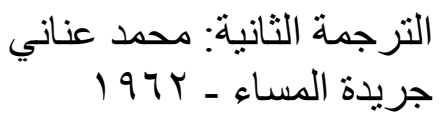




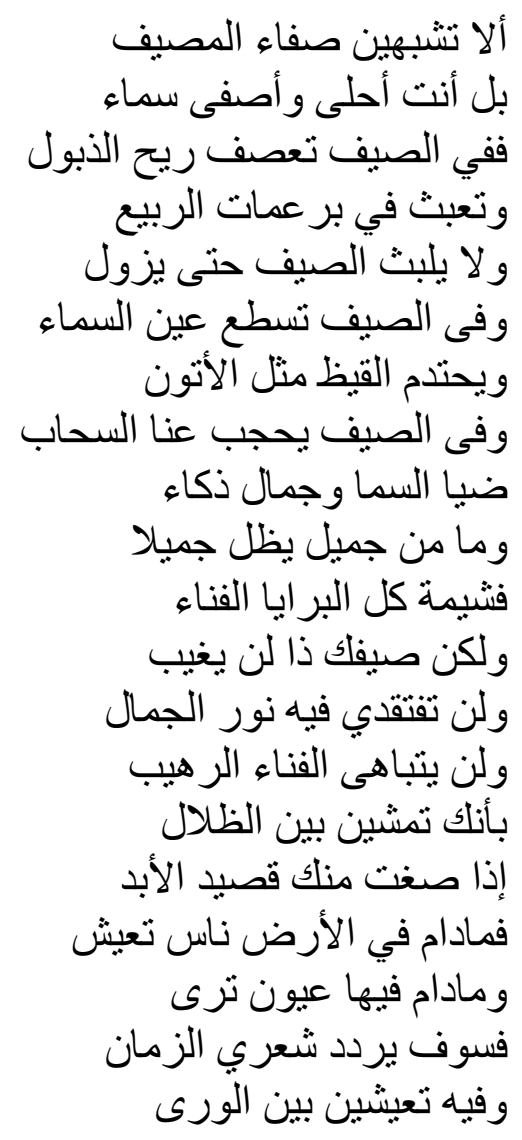

\section{Analysis:}

Enani has come up with a domesticated version of the poem. He did not commit himself to the form of the original that of 3 quatrains and a couplet. Enani outnumbers the lines of the original in order to create an acceptable Arabic poem to TRs. Enani follows Lefevere's metrical pattern, because he makes a regular meter called Tripping Meter that made the tempo of the poem become faster. Enani creates a regular meter and an occasional rhyme with the purpose of giving birth a newborn poem.

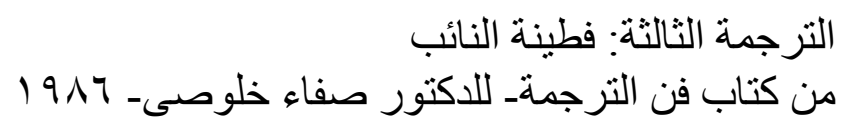




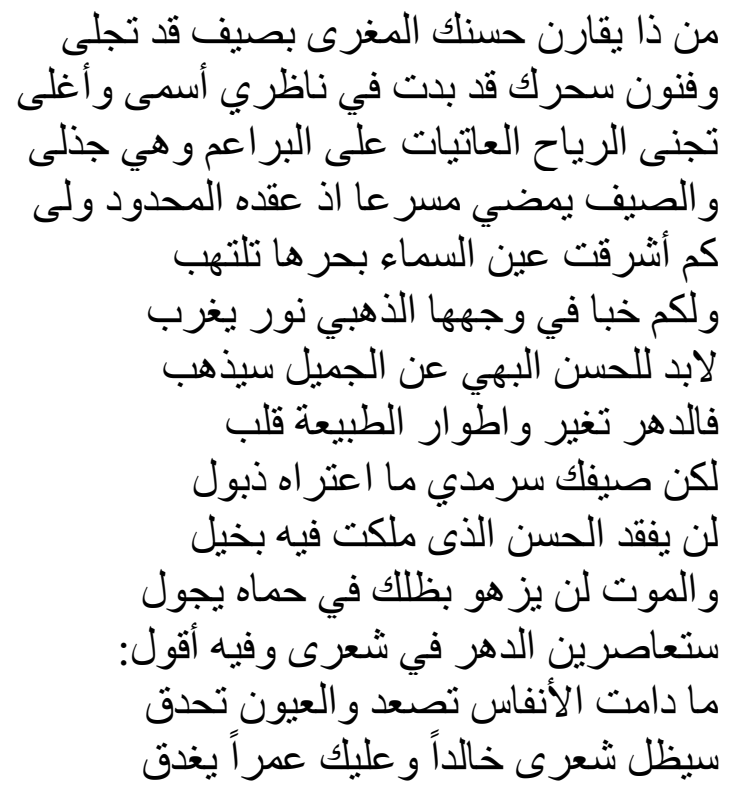

\section{Analysis:}

This translator neutralizes the text. She utilizes neutralization technique when rendering such a poem. First, Fatina, the poet, has rightly committed herself to the same number of lines, which are 14. On the other hand, she has come up with a genuine prosodic pattern in Arabic with an internal rhythm and an occasional rhyme. Fatina does some semantic and syntactic elaborations together with some figurative deviations to keep pace with her purpose that is to neutralize the product.

$$
\begin{aligned}
& \text { الترجمة الر ابعة: حسن غز الة }
\end{aligned}
$$

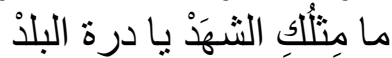

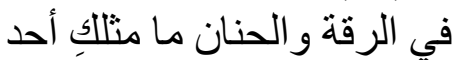

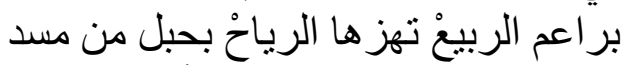

$$
\begin{aligned}
& \text { و الصيف صبفنا قصبر في الأمد الردا } \\
& \text { وشمس صيفنا أوار ها اتقدا } \\
& \text { شعاعها المذهب في غالب خمد } \\
& \text { ورونق الجمال جماله نفد غالد الأب } \\
& \text { فلا دو ام إلا للو احد الأحد } \\
& \text { يا درة البلد ذبوإلك محال، بها للأد الأبد }
\end{aligned}
$$




\section{Analysis:}

$$
\begin{aligned}
& \text { بهاؤك الذي مزدانة به حُزتيه للأبد }
\end{aligned}
$$

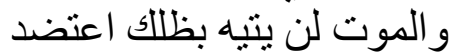

$$
\begin{aligned}
& \text { أبيات من قصيد خلاتلك فيها سبحان من وجد ألاند } \\
& \text { خلودك باق إذا الأنفاس و الأبصار لم تُبَّنْ } \\
& \text { خلود سرمدي يحييك بالمدذ الأن }
\end{aligned}
$$

Domestication is so evident in Ghazala's rendering. He has produced a perfect rhyme scheme throughout the entire poem. He has borrowed many words from his Islamic culture background that seems in his lexical choices and expressions that are intertextualized from the Holy Quran. He has committed many variations and deviations from Shakespearean sonnet that made the product quite far from English culture.

$$
\begin{aligned}
& \text { الترجمة الخامسة: عبد الصاحب مهدي علي }
\end{aligned}
$$

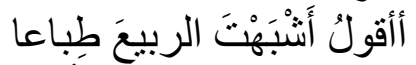

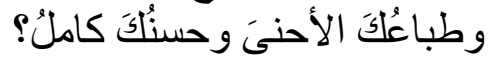

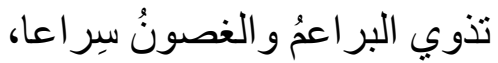

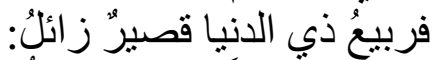

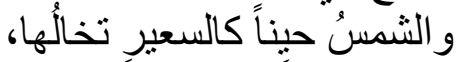

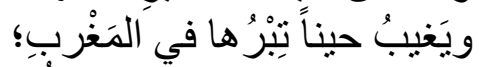

$$
\begin{aligned}
& \text { ويزورُ عن ذاتِ الجمالِِ جمالُها، }
\end{aligned}
$$

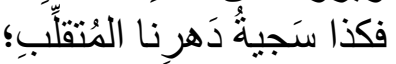

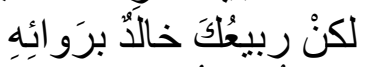

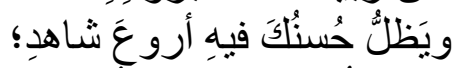

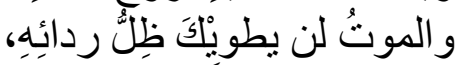

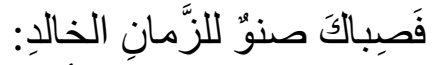

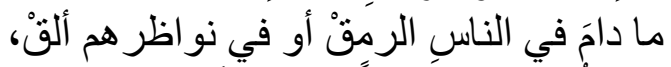

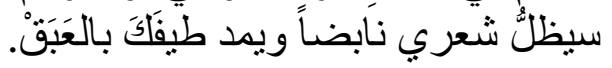

\section{Analysis:}

Likewise, Ali adopts domestication approach in his translation. He did not use the direct correspondent of the 'summer' into Arabic, but he employs the cultural equivalent in Arab culture that is 'spring', which is considered the best season in the entire year, and regarded as the symbol of beauty and clemency. The 
translator in question pleads the line of Al-Buhturi when saying "أتاك الربيع الطلق يختال ضاحكاً / من الحسن حتى كاد أن يتكلما". the translation employs Lefevere's metrical translation, that is quite clear in the rhyme scheme which runs as the same as the original runs, as follows: ab ab/cd cd/ef ef/gg.

\section{Conclusion}

\section{Findings:}

\section{To Domesticate or to Foreignize?}

The choice between the two concepts is not haphazard but context-bound. In other words, the choice of the domestication and/or foreignization is not fixed; however, they could co-exist even in the same text. Moreover, the two methods should supplement and complement each other in terms of time and space factors in poetic translation. The conclusion is that domestication approach was frequently used in the process poetry translation.

The translator of the target text tends to use the domestication strategy because domestication designates the type of translation in which a transparent, fluent style is adopted to minimize the strangeness of the foreign text for target language readers, while foreignization means that a target text is produced which deliberately breaks target conventions by retaining something of the foreignness of the original.

It is proved in this analysis that domestication is dominant compared with foreignization. Translation of literary works of a community is a way of cultural exchange and interaction; if cultural exchanges take place instead of cultural hegemony, both cultures will benefit. In fact, the strategy used in translation of a literary work determines whether translation is a cultural interaction channel or a tool for cultural hegemony. This study contributes to enlightening poetry 
translators of utilizing such approaches and strategies when rendering in a more effective manner.

The results of the present research may help poetry translators to have background knowledge about different practical approaches and strategies employed in poetry translation. Since the selected poems in question are in different forms of verse, translators are expected to follow a specific model or pattern in translating these forms. Besides, the findings of the current study may assist translation studies scholars, investigators, researchers, students and others who are interested in poetry translation to have some new notions about the methods of poetry translation.

\section{Answering Research Questions:}

The study answers the THREE questions that have been raised in the first Chapter.

The first question was:

How do Venuti's two approaches be used and applied to poetry translation and why?

The answer is:

Venuti's two approaches should supplement and complement each other in poetic translation. Domestication and foreignization are eligible and highly readable in poetry rendering, as they are descriptive approaches and by no means prescriptive ones, in other words, they are applicable and not merely theoretical approaches.

The second question was:

What is the most frequently used translation strategy (domestication and foreignization) in translating the selected poems?

The answer is:

The domestication approach was frequently used in the process of poetry translation. 


\section{Domestication versus Foreignization}

The third question was:

Which approach of Venuti's two approaches and Lefevere's seven strategies can fit properly in the translation of poetry to maintain its nature?

The answer is:

Venuti's domestication is more proper in the status quo of poetry translation and the most frequently used of Lefevere's strategies are rhymed translation and blank verse translation.

\section{Bibliography}

Bassnet, S. \& Lefevere, A. (1990). Translation, History and Culture. London: Printer Publishers.

Enani, M. (1997). Literary Translation. Cairo: Libraire du Liban. (2003). Art of Translation. Cairo: Longman.

(2003). Modern Theory of Translation: Introducing Translations Studies. Cairo: Longman.

Ghazala, H.S. (2008). Translation as Problems and Solutions: A Textbook for University Students and Trainee Translators. Lebanon: Dar El- Ilm Lilmalayian.

Jakobson, R. (1959). On Linguistic Aspects of Translation. In: Lawrence Venuti (ed.), The Translation Studies Reader. London. New York: Routledge.

Lefevere, A. (1975). Translating Poetry: Seven Strategies and a Blueprint. Assen and Amsterdam: van Gorcum.

Mazid, B. M. (2008). An English-Arabic Translation Course-book: With an Arabic-English Translation Supplement. Cairo: ALTHURAYA.

Metatext.

(2016). World, Text and Translation: Translation as

(2017). Poetry from Analysis to Translation. Cairo:

Noor Publishing.

(2018). A Poison Tree. Cairo: National Center for Translation. 
Munday, J. (2001). Introducing Translation Studies: Theories and Applications. London and New York: Routledge.

Newmark, P. (1981). Approaches to Translation, Oxford, New York, Pergamon Press.

Prentice

(1988). A Textbook of Translation, New York, London,

Hall.

(1983). Paragraphs on Translation. Clevedon, Philadelphia and Adelaide: Multilingual Matters LTD.

Nida, E. (1964). Toward a Science of Translating. Leiden: E. J. Brill.

Corp.

(1984). On translation. Beijing: Translation Publishing

(1993). Language, culture and translation. Shanghai:

Shanghai Foreign Language Education Press.

(2001). Contexts in translating. Amsterdam: John

Benjamins.

Nida, E. \& Taber C. (1993). The Theory and Practice of Translation.

Shanghai: Shanghai Foreign Language Education Press.

Venuti, L. (1991). Genealogies of Translation Theory:

Schleiermacher. Traduction, Terminologie, Rédaction. Vol.4, (pp. 125-150).

(ed.) (1992). Rethinking Translation: Discourse,

Subjectivity, Ideology. London and NY: Routledge.

(1993). Translation as cultural politics: Regimes of

domestication and foreignnization. Textual Practice 7(2) 1993:

208-223.

(1995). The Translator's Invisibility: A History of

Translation. London and New York: Routledge.

(1998). The Scandals of Translation: Towards an Ethics

of Difference. London and New York: Routledge.

(ed.) (2000). The Translation Studies Reader. London and New York: Routledge.

(2009). Translation, intertextuality, interpretation. Romance Studies 27(3): 157-173. 
